Milena M. Letić, DOI: $10.19090 /$ zop.2016.25.57-74

Biljana S. Lungulov UDC: $159.928:[316.62: 159.923 .2$

Univerzitet u Novom Sadu, Pregledni rad Filozofski fakultet

\title{
VANINTELEKTUALNI ČINIOCI OSTVARENJA DAROVITOSTI ${ }^{1}$
}

Apstrakt: Polazeći od savremenih koncepcija darovitosti koje naglašavaju značaj personalnih i sredinskih karakteristika za aktuelizaciju visokih sposobnosti, autorke rada, koristeći metodu teorijske analize, daju pregled istraživanja povezanosti svojstava ličnosti i sredinskih prilika sa ostvarenjem darovitosti. Učinjen je pokušaj da se upotpune saznanja o vanintelektualnoj sferi darovitih u nadi da će se tako dobiti obuhvatnija slika činilaca ostvarenja darovitosti od one kojom se danas raspolaže.

Opšti nalaz svih pomenutih istraživanja sadržan je u konstataciji da sudbina izuzetnih potencijala umnogome zavisi od vanintelektualnih činilaca. Natprosečne sposobnosti su svakako važan elemenat darovitosti, jer omogućuju kvalitetnije bavljenje određenim aktivnostima, ali, same po sebi, one nisu dovoljne da bi se darovitost iskazala u izuzetnim postignućima.

Premda osobe darovite u različitim domenima imaju mnoge zajedničke karakteristike, njihovi profili ličnosti, kao i sredinske prilike, pokazuju i određene specifičnosti, što upućuje na konstataciju da se fenomen darovitosti može precizno sagledati jedino ako se locira u okvire pojedinačnih domena. Stoga, autorke zaključuju da osim multidimenzionalnosti, kao krucijalnog modernog obeležja konstrukta darovitosti, referentni okvir istraživanja ovog problema mora biti definisan i u terminima konkretnog domena manifestovanja izvrsnosti.

Ključne reči: darovitost, ostvarenje darovitosti, svojstva ličnosti, sredinske prilike.

\footnotetext{
${ }^{1}$ Članak predstavlja rezultat rada na projektu "Kvalitet obrazovnog sistema Srbije u evropskoj perspektivi”, br. 179010 (2011-2016), čiju realizaciju finansira Ministarstvo za nauku i tehnološki razvoj Republike Srbije.

Milena Letić, milenaletic@ff.uns.ac.rs, Biljana Lungulov biljana.lungulov@ff.uns.ac.rs
} 


\section{Uvod}

Zaslugom autora savremenih koncepcija skrenuta je pažnja na dinamičnu prirodu darovitosti koja nameće potrebu za razmatranjem ovog fenomena u relaciji sa činiocima iz vanintelektualne sfere. Preciznije rečeno, za razliku od nekadašnjeg "fiksiranja" darovitosti unutar okvira opšte inteligencije, autori modernih koncepcija insistiraju na posmatranju ovog fenomena kao razvojnog procesa koji beleži postupno uzrastanje potencijala u izuzetan učinak. Ova transformacija je značajno determinisana specifičnom konstelacijom vanintelektualnih činilaca koji su povezani kako sa prostorom ličnosti, tako i sa sredinskim kontekstom.

Premda se načelni stav nauke o ovoj problematici svodi na kvalifikovanje personalnih obeležja i sredinskih prilika kao "esencijalnih činilaca" za razvoj darovitosti (Freeman, 2000), istovremeno se naglašava da se nesumnjiv uticaj ovih faktora ne može proglašavati generatorskim (Freeman, 2000; Winner, 1996). Drugim rečima, mnogo je uputnije konstatovati da povoljna konstelacija vanintelektualnih činilaca ne predstavlja ishodište darovitosti, već da samo potpomaže preobraćanje visokih potencijala u zapaženi učinak u određenom domenu. U skladu sa teorijskim okvirom "diferenciranih modela darovitosti", doprinos vanintelektualnih činilaca razvoju darovitosti mogao bi se opisati i u terminima "katalizatora", odnosno "moderatora" razvojnog procesa koji kao polaznu osnovu ima visoke specifične sposobnosti, a kao krajnji ishod izuzetno postignuce u određenoj oblasti (Gagné, 2005; Heller, Perleth \& Lim, 2005).

Teorijska razmatranja prirode uticaja vanintelektualnih činilaca na razvoj darovitosti u saglasnosti su sa zaključcima empirijskih studija ove problematike. Naime, s obzirom na činjenicu da su nacrti istraživanja u ovoj oblasti većinom sledili načela korelacionih istraživanja, na više mesta u literaturi se ističe da se o delovanju faktora ličnosti i sredine na aktualizaciju potencijala ne može govoriti u terminima kauzalnog odnosa, već samo uzajamne povezanosti koja je vrlo verovatno dvosmernog tipa, što znači da odgovarajuća svojstva ličnosti i sredinske prilike predstavljaju antecedente razvoja darovitosti, ali i da se neke varijable iz pomenutih aspekata mogu javiti i kao rezultat izuzetnih postignuća.

Ostvarenje u kontekstu darovitosti, najčešće je ispitivano u akademskoj, odnosno profesionalnoj sferi, pri čemu je u literaturi moguće naići na različite operacionalizacije ove varijable. Kao najčešći pokazatelji 
izvrsnosti, pominju se opšti školski uspeh, ocene iz relevantnih nastavnih predmeta, postignuća na standardizovanim testovima znanja, nastavničke procene uspešnosti učenika, rang u odeljenju utvrđen na osnovu procena uspešnosti od strane ostalih učenika, te nagrade i specijalna školska postignuća (Štula, 2007). S obzirom na brojne varijacije u indikatorima ostvarenja darovitosti, izvestan broj autora se zalaže za operacionalizovanje ovog konstrukta posredstvom multiplih kriterijuma (Howley, Howley \& Pendarvis, 1986; Reynolds \& Birch, 1977; Richert, Alvino \& McDonnel, 1982, svi prema: Feldhusen \& Jarwan, 2000). Međutim, diskursi na ovu temu mogli bi se sažeti u zapažanje da "nije od presudnog značaja koliko mera koristimo ... već koliki doprinos svaki pojedinačni podatak ima u donošenju valjane odluke" (Piirto, 1994, prema: Feldhusen \& Jarwan, 2000: 274).

Bez obzira na manja ili veća razilaženja u shvatanjima najprimerenijeg načina operacionalizovanja kriterijumske varijable, važnost vanintelektualnih činilaca $u$ ostvarivanju zapaženog učinka predstavlja mesto opšteg konsenzusa među različitim izučavaocima ove problematike. Otuda nimalo ne iznenađuje podatak da su autori brojnih studija o darovitosti umeravali svoj istraživački fokus na prostor ličnosti i sredine, tragajući za konstelacijama varijabli iz pomenutih aspekata koje bi ponudile temeljno tumačenje nečijeg ostvarenja na nivou na kojem njegova postignuća udovoljavaju kriterijumima izvrsnosti.

\section{Istraživanja povezanosti svojstava ličnosti i ostvarenja darovitosti}

Moglo bi se reći da stanovište o relevantnosti povezivanja svojstva ličnosti sa ostvarenjem darovitosti datira još od Termanove longitudinalne studije, koja, premda priklonjena tendencijama glorifikovanja opšte inteligencije kao isključivog činioca uspešnosti darovitih, na kraju priznaje postojanje udruženog delovanja intelektualnih i individualnih, tj. personalnih činilaca ove problematike. Ovakva saznanja doprinela su konstituisanju važne linije istraživanja koja pretenduje da rasvetli ličnosnu pozadinu darovitosti i ponudi odgovor na pitanje: koji kvaliteti ličnosti odlikuju darovite pojedince i po pretpostavci objašnjavaju njihov uspeh da realizuju sopstveni potencijal?

Kada bismo varijable iz ove kategorije rangirali spram veličine doprinosa u objašnjenju varijabiliteta ostvarenja darovitosti, najvišu poziciju bi zauzela motivaciona svojstva ličnosti. Naime, u određenim istraživanjima 
ove problematike ustanovljeno je da motivaciona svojstva, odmah posle sposobnosti, ostvaruju najrelevantniji doprinos ostvarenju darovitosti u različitim domenima, te da se vrednosti koeficijenata korelacije ove grupe prediktora i kriterijumske varijable kreću u rasponu 0.20-0.35 (McCoach, 2002; Uguroglu \& Walberg, 1979; Hansford \& Hattie, 1982, prema: Trost, 2000). Pri tome se, pre svega, misli na onaj vid motivacije koji pojedini autori nazivaju posvećenost zadatku ili orijentacija na zadatak, a koji se prevashodno manifestuje kroz spremnost na ulaganje velikog truda i napora u ovladavanju određenim domenom, te perzistenciju u obavljanju ovih aktivnosti i pored nailaženja na brojne prepreke (Ames, 1992). Orijentaciji na zadatak obično se suprostavlja orijentacija na takmičenje, čiji krajnji cilj nije znanje, već nadmetanje sa drugima, odnosno "veličanje ega" (Ames, 1992, prema: Štula, 2007). Međutim, podrobnija razmatranja motivacije za takmičenje ukazala su da je nadmetanje sa drugima samo jedan njen aspekt, te da, osim želje za nadvladavanjem drugih, učenike na takmičenje motiviše i želja za unapređivanjem vlastite kompetencije u određenom domenu (Franken \& Brown, 1995). Stoga se na pojedinim mestima u literaturi naznačava da motivacija za takmičenje može podrazumevati dva vida: takmičenje sa samim sobom i takmičenje sa drugima (Rimm, 1986, prema: Udvari \& Schneider, 2000). Pri tome je ustanovljeno da prvi vid takmičenja unapređuje uspešnost učenika u određenom domenu, otuda što takvi učenici pokazuju sklonost ka upuštanju u kompleksne zadatke koji iziskuju poseban napor i istrajnost u radu, dok takmičenje sa drugima podrazumeva preferenciju lakših zadataka, u kojima se sa minimalnim naporima ostvaruje prednost u odnosu na ostale pojedince angažovane na istim zadacima (Tassi \& Schneider, 1997, prema: Udvari \& Schneider, 2000). Stoga nimalo ne iznenađuje što se na pojedinim mestima u literaturi posvećenost zadatku ne opisuje samo u terminima pomenute spremnosti na napore i perzistencije u radu, već i u terminima kompetitivnosti (Trost, 2000), pri čemu se, sasvim izvesno, misli na kompetitivnost u formi takmičenja sa samim sobom.

Ostvarenje darovitosti dovodi se u vezu i sa psihosocijalnom prilagođenošću i veštinama samoregulacije, koje pri tome pokrivaju širu grupu činilaca različitog nivoa složenosti: od specifičnih svojstava ličnosti kao što je perfekcionizam, do načina na koji je darovita osoba formirala svoj identitet (Altaras, 2006).

Bez obzira na nedostatak ekvivalentnih kvantitativnih pokazatelja, uspešnim darovitim osobama često se pripisuje perfekcionizam (Lovecky, 
1992; Parker \& Adkins, 1995; Siegle \& Schuler, 2000). Premda pojedini autori o ovom svojstvu govore u terminima sile koja može da parališe svaki napredak (Baker, Bridger \& Evans, 1998; Baum, Renzulli, Hébert, 1995; Díaz, 1998; Ford, 1993), visoke aspiracije i strogi kriterijumi koji prate ovo svojstvo mogu biti korisni "saveznici" u ostvarivanju vrhunskih postignuća. Shodno tome, nalaz da uspešni daroviti učenici jače od svojih manje uspešnih vršnjaka teže tome da saznaju više ili urade bolje ni na koji način ne može biti sporan. Štaviše, mnogi bi se saglasili i sa postavkom Vinerove (1996), prema kojoj ova težnja predstavlja inherentno svojstvo izuzetne sposobnosti.

Brojni istraživači ukazuju na postojanje linearne povezanosti pozitivnog self-koncepta darovitih sa ostvarenjem u različitim domenima (Baker, Bridger \& Evans, 1998; Díaz, 1998; Ford, 1993; Marsh et al., 1995, prema: McCoach, 2002; Peters, Grager-Loidl \& Supplee, 2000; Reis \& McCoach, 2000), koja sugeriše da ovaj činilac objašnjava čak trećinu varijanse kriterijumske varijable (Lyon, 1993, prema: Štula, 2007). Pozitivan self-koncept podrazumeva visoko samopoštovanje i pozitivnu sliku o sebi, visoko samopouzdanje i poverenje u sopstvene sposobnosti, odsustvo osećanja inferiornosti, te uverenje osobe da se dopada drugima. Imajući u vidu da - makar uslovno rečeno - daroviti postaju ono što o sebi misle (Barbe, 1978, prema: Maddux, Scheiber \& Bass, 1982), jasno je zbog čega se pozitivnom self-konceptu pripisuje značajan doprinos u realizaciji visokih potencijala.

Ko bi rekao da broj sekundi tokom kojih jedan predškolac uspeva da odoli slatkišima izuzetno dobro predviđa njegova postignuća i generalnu efikasnost u adolescenciji i odraslom dobu (Ayduk \& Mischel, 2002)? Ovaj interesantan nalaz, između ostalog, ilustruje da sposobnost samokontrole $\mathrm{i}$ veštine samoregulacije igraju izrazito važnu ulogu u realizaciji potencijala. Kako brojni istraživači primećuju, uspešni daroviti učenici često pokazuju visoku kontrolu nad svojim ponašanjem i emocijama, što se odražava kako na intrapersonalni plan i socijalne odnose, tako i na njihovu efikasnost, odnosno postignuće (Baum, Renzulli, Hébert, 1995; Díaz, 1998; Peters, Grager-Loidl \& Supplee, 2000; Reis \& McCoach, 2000; Renzulli \& Park, 2000).

Polazeći od pretpostavke da ishod procesa formiranja identiteta predstavlja važan faktor postignuća u kasnoj adolescenciji i odraslom dobu, Zuova i Krejmondova (Zuo \& Cramond, 2001) su pokušale da primene Eriksonovu teoriju (odnosno Marsijinu klasifikaciju statusa 
identiteta) ${ }^{2}$ u svojoj analizi Termanovih podataka o najuspešnijim (A grupa) i najmanje uspešnim "Termitima" (C grupa). Snaga Eriksonove teorije u objašnjavanju profesionalnog postignuća neke osobe proističe iz njene mogućnosti da sažme brojne vanintelektualne faktore za koje je utvrđeno da doprinose uspehu. Motivacija, usmerenost na cilj, istrajnost i snaga karaktera mogu se posmatrati kao indikatori dubljeg konstrukta, naime doživljaja sopstvenog identiteta. Upravo ovaj doživljaj identiteta čini da osoba bude fokusirana i motivisana u svojim naporima da ostvari postavljene profesionalne ciljeve (Zuo \& Cramond, 2001), dok ju, obrnuto, nedostatak jasnog doživljaja identiteta može sprečiti da realizuje svoj potencijal. U skladu sa tim, Zuova i Krejmondova su pretpostavile da se za "osobe uobličenog (samoodređenog) identiteta" (identity achievers) može očekivati da će zabeležiti veće postignuće u životu u poređenju sa osobama koje imaju drugačiji status identiteta, naročito u poređenju sa "osobama difuznog (neodređenog) identiteta" (identity diffusers). Rezultati njihove studije potvrđuju ovu hipotezu: dok su "Termiti" iz A grupe bili većinom "osobe uobličenog identiteta" koje su znale svoj cilj i pravac u životu, za "Termite" iz C grupe ispostavilo se da su uglavnom "osobe neodređenog identiteta" koje besciljno tumaraju kroz svoj život (Zuo \& Cramond, 2001). Dodatnu potvrdu ovim nalazima pruža longitudinalno istraživanje Pitersonove koje pokazuje da uspešni daroviti učenici uspevaju da odrede pravac svoje karijere značajno ranije i sa značajno većom sigurnošću nego manje uspešni (Peterson, 2001).

Ostvarenje darovitosti dovodi se u vezu i sa prijemčivošću za bavljenje etičkim pitanjima (Olenchak, 1999; Edmunds, Edmunds, 2005). Istraživači poput Linde Silverman (Silverman 1994; 1998), Dijedri Lovecki (Lovecky, 1997), Majrese Gros (Gross, 1998), Marte Morlok (Morelock, 1997) ili Stefani Toulan (Tolan, 1998), koje proučavaju slučajeve izrazito darovite dece, smatraju da darovitost podrazumeva povišenu sposobnost za konstrukciju značenja u kontekstu iskustva, što doprinosi složenosti emocionalnog i moralnog života darovite osobe. Kao posebno važan aspekt sveukupnog "doživljaja darovitosti", ove autorke ističu naročitu moralnu osettjivost darovite dece (Gross, 1998; Lovecky, 1997; Morelock, 1997; Silverman, 1994; 1998; Tolan, 1998). One se pri tom pozivaju prvenstveno na nalaze iz sopstvene istraživačke i kliničke prakse ističući, međutim, ${ }^{2}$ Ukrštanjem dimenzija eksploracije (prošao krizu - nije prošao krizu) i opredeljenosti definisana su 4 statusa identiteta: samoodređenost (identity achievement), jošneodređenost (moratorium), predodređnost (foreclosure) i neodređenost identiteta (identity diffusion) (Marcia, 1980, prema: Zuo \& Cramond, 2001). 
da je kamen temeljac za njihovo stanovište postavljen još u "klasičnim" studijama darovite dece: Termanovi ispitanici ("Termiti") su, naime, pokazivali značajnu naprednost na merama "pouzdanosti”" (trustworthiness) i "moralne stabilnosti", a Holingvortova je primetila snažno interesovanje za etička i moralna pitanja na svom uzorku ekstremno darovitih ispitanika (Terman, 1925, Hollingworth, 1942, prema: Gross, 1998). Šta se zapravo ima u vidu kada se govori o moralnoj osetljivosti? U prvom redu svakako činjenica da je kod darovite dece primećeno rano buđenje moralne svesnosti (early moral awareness), odnosno rana i intenzivna zaokupljenost moralnim pitanjima: dok većina njihovih vršnjaka provodi vreme igrajući se u "blaženom neznanju", darovita deca sa velikim žarom razmišljaju o problemima pravde i krivde, dovode u pitanje ustaljena "pravila igre", a svojim, najčešće zatečenim, roditeljima upućuju niz uznemiravajućih pitanja (Lovecky, 1997; Tolan, 1998; Winner, 1996), ostavljajući utisak da imaju gotovo "urođen osećaj" za to šta je moralno ispravno (Silverman, 1994). No, moralna osetljivost darovite dece najčešće prevazilazi puko razmatranje etičkih pitanja i obično podrazumeva i odgovarajuće moralno ponašanje. Prema nalazima pomenutih autorki, mnoga darovita deca veoma rano ispoljavaju saosećanje i želju da ublaže tuđu patnju, kao i sposobnost da zauzmu čvrst moralni stav i ponašaju se u skladu sa nekim načelom (Lovecky, 1997). Silvermanova smatra da su, usled potrebe za logičkom doslednošću, darovita deca "strastveno privržena istini", da se "gnušaju sopstvene i tuđe nedoslednosti” i da im je teško da opravdaju i razumeju bilo kakvo izvrtanje istine (Silverman, 1998). Treba, međutim, istaći da "sposobnost da se bude milosrdan ili da se zauzme moralni stav o tome šta je ispravno i pravedno, ne znači nužno da će dete umeti i da artikuliše razloge takvog ponašanja" (Lovecky, 1997, prema: Altaras, 2006: 102). Moralnu osetljivost stoga ne treba izjednačavati sa moralnim rezonovanjem. Kada je u pitanju ovo drugo, poređenja darovite i prosečne dece ne daju jednoznačne nalaze: neka istraživanja ukazuju na to da daroviti postižu značajno više skorove na merama moralnog suđenja i da brže napreduju kroz stadijume moralnog razvoja (Gross, 1998; Morelock, 1997), dok druga pokazuju da, uprkos nešto boljim skorovima na testovima moralnog rezonovanja, darovita deca funkcionišu na istom nivou moralnog razvoja kao njihovi prosečni vršnjaci (Tan-Willman \& Gutteridge, 1981).

Što se tiče nekih drugih svojstava ličnosti, autori istraživanja ostvarenja u kontekstu različitih domena darovitosti ustanovili su važnost kreativnosti (Karimi, 2000, Mohamad Taghi Mahmodi, 1998, 
prema: Naderi, Abdullah, Aizan, Sharir, \& Kumar, 2010; Feldhusen, Treffinger \& Elias, 1970, prema: Palaniappan, 2005; Torrance, 1962, prema: Torrance, 2004). Ovakvi nalazi se na nekim mestima interpretiraju kao pokazatelji mogućnosti kompenzovanja osrednje inteligencije kreativnošću (Palaniappan, 2005), premda ima i autora koji u ovakvom odnosu kreativnosti i postignuća vide smernicu za koncipiranje okvira identifikacije darovitih učenika koji bi, uz ostale relevantne indikatore, nužno sadržavao i podatak o nivou kreativnosti učenika (Torrance, 2004).

Ima i takvih istraživanja koja činioce uspešnosti darovitih pojedinaca utvrđuju u prostoru većeg broja različitih dimenzija ličnosti. Tako je ustanovljeno da osobine ličnosti iz sfere "velikih pet" predstavljaju najsnažnije prediktore uspeha u školi, kako na nivou osnovnog, tako i na nivou srednjeg i visokog obrazovanja (Poropat, 2009). Pri tome, osobine savesnosti (O'Connor \& Paunonen, 2007) i otvorenosti ka iskustvu (Laidra, Pullmann \& Allik, 2007) dosledno su se pokazale kao najsnažniji prediktori školskog uspeha darovitih. Većina istraživanja pokazuje da osobine saradljivost (prijatnost) i školski uspeh nisu povezani (Chamorro-Premuzic \& Furnham, 2003), a, kada su u pitanju neuroticizam (emocioionalna nestabilnost) i ekstraverzija, rezultati su prilično nedosledni (O'Connor $\&$ Paunonen, 2007). Dok pojedina istraživanja pokazuju da neuroticizam i školski uspeh nisu povezani (Martin, Montgomery \& Saphian, 2006), druga, pak, ukazuju na to da daroviti sa višim nivoom emocionalne nestabilnosti postižu lošije rezultate u školi (Poropat, 2011).

Autori znatnog broja istraživanja ove vrste pretendovali su da ustanove prediktivni doprinos bazičnih tipova ličnosti preuzetih iz Jungove teorije psiholoških tipova. Na ovaj način pribavljeni su nalazi koji upućuju na najfrekventniju zastupljenost "intuitivnog" i "perceptivnog" tipa ličnosti u populaciji darovitih, pri čemu prvi tip podrazumeva veću razvijenost osobina imaginativnosti, analitičnosti i kreativnosti, dok se drugi tip opisuje u terminima spontanosti, fleksibilnosti i receptivnosti (Geiger 1992, Hawkins 1997, Jackson 1989, Mills, Parker 1998, svi prema: Sak 2004).

Osim pomenutih, autori pojedinih istraživanja istakli su važnost još nekih svojstava ličnosti, uzimajući, međutim, u obzir ostvarenje darovitosti u konkretnim domenima. Shodno tome, postoje nalazi koji visoka postignuća umetnički darovitih pojedinaca dovode u vezu sa naglašenim nonkonformizmom shvaćenim kao sklonost ka preispitivanju socijalnih normi i vrednosti (Csikszentmihalyi \& Getzels, 1973, Kemp, 
1981, prema: Feist, 1999; Pekić, 2010), dok je za kategoriju akademski darovitih ustanovljena tendencija ka ostvarivanju višeg skora na dimenziji savesnosti, koja obuhvata sledeće crte ličnosti: organizovanost, sklonost ka planiranju, odgovornost i red (John 1990, prema: Feist 1999; Pekić, 2010). Druga istraživanja ove vrste ukazuju na to da se umetnički i akademski daroviti pojedinci razlikuju i u emocionalnoj sferi otuda što prve karakteriše dispozicija ka intenzivnijim emocionalnim doživljajima (Andreasen, Glick 1988, prema: Fiest 1999; Pekić, 2010), što pojedini autori tumače osobenostima datih domena odnosno činjenicom da domen umetnosti podstiče introspektivnost i upućenost na intrapsihički plan, dok akademske domene odlikuje fokusiranost na spoljnu realnost (Gardner 1973, prema: Fiest 1999; Pekić, 2010). U vezi sa emocionalnim funkcionisanjem darovitih, u ova dva domena su i nalazi koji ukazuju na to da umetnički darovite pojedince u odnosu na akademski darovite odlikuje niži stepen emocionalne zrelosti, što se dovodi u relaciju sa razlikama $\mathrm{u}$ vaspitanju darovite dece u zavisnosti od vrste domena, što će se podrobnije razmatrati u nastavku rada (Freeman, 2000, prema: Pekić, 2010).

$\mathrm{Na}$ kraju, treba pomenuti da veza između svojstava ličnosti i visokih postignuća predstavlja jednu od najaktuelnijih tema u istraživanju darovitosti, te da u skorijoj budućnosti možemo očekivati više saznanja o tome kako određene konstelacije svojstava ličnosti doprinose sticanju znanja u nekom domenu čineći da učenici odgovarajućeg profila budu podložni uspehu u tom domenu.

\section{Istraživanja povezanosti sredinskih prilika i ostvarenja darovitosti}

Istraživanja koja su za predmet imala razmatranje ostvarenja darovitosti u aspektu sredinskih prilika pretežno su bila upravljena na analize porodičnog miljea darovitih pojedinaca. Naime, u poduhvatima ovakve vrste nastojalo se ispitati da li su porodice sa darovitim detetom organizovane na specifičan način, odnosno da li postoji relacija između porodičnog okruženja darovitih pojedinaca i njihove naprednosti u nekom od domena. U relevantnoj literaturi koja sistematizuje nalaze različitih istraživanja ovog problema navodi se šest opštih karakteristika porodica sa darovitim detetom: 1) darovita deca zauzimaju "posebno mesto" u porodici i u najvećem broju slučajeva to su jedinci ili prvorođena deca, 2) darovita deca odrastaju u stimulativnom porodičnom okruženju, 3) roditelji darovite dece su usredsređeni na njihov napredak u određenom 
domenu, 4) roditelji darovite dece su skloni postavljanju veoma visokih standarda uspešnosti te konsekventno imaju i visoka očekivanja od dece, 5) istovremeno, ovi roditelji deci dozvoljavaju ostvarivanje nezavisnosti, 6) konačno, najpogodnijom kombinacijom porodičnih uslova za ostvarenje darovitosti pokazala se ona koja podrazumeva visoke standarde i očekivanja, na jednoj, i podršku roditelja, na drugoj strani (Winner, 1996, prema: Pekić, 2010).

Kada je reč o ostvarenju u konkretnim domenima, pojedina istraživanja pokazuju da roditelji dece koja su darovita u domenu muzike imaju najdirektivniji pristup, odnosno da su roditelji dece koja su darovita u domenu vizuelnih umetnosti u najmanjoj meri direktivni, dok se za roditelje akademski darovite dece ispostavilo da su u pogledu direktivnosti "negde između" prethodne dve grupe (Bloom, 1985, prema: Winner, 1996). U istom istraživanju ustanovljeno je da su roditelji muzički darovite dece i sami bili zainteresovani za ovu oblast, bilo da su imali formalno muzičko obrazovanje bilo da su bili pasionirani konzumenti klasične muzike. Njihova direktivnost u pristupu ogledala se u usmeravanju deteta ka domenu muzike, prevashodno u vidu pokretanja inicijative za učenje nekog muzičkog instrumenta, da bi u daljem toku detetovog ovladavanja elementima muzike aktivnije učestvovali u praćenju njegovog napredovanja postavljajući vrlo visoke standarde uspešnosti. Roditelji dece darovite za vizuelne umetnosti u najvećem broju slučajeva nisu pokazivali poseban interes za ovaj domen, te usmerenost dece ka tome sa njihove strane nije bila niti podsticana niti sputavana. Njihov pristup u vaspitanju podrazumevao je favorizovanje samoaktuelizacije, bez nametanja vlastitih preferencija domena i aktivnog praćenja detetovog napredovanja. Kada je reč o roditeljima dece darovite u akademskim domenima, njihov "srednji način" ophođenja prema deci podrazumevao je da su poput roditelja muzički darovite dece podsticali naporan rad postavljajući visoke standarde uspešnosti, no slično roditeljima dece darovite za vizuelne umetnosti, pokazivali su priličnu indolentnost prema vrsti domena manifestovanja darovitosti favorizujući samoaktuelizaciju kao takvu. Moguće objašnjenje razlika u stepenu direktivnosti roditeljskog pristupa u zavisnosti od vrste domena Vinerova pronalazi u različitom društvenom vrednovanju ovih domena, pri čemu se (u zapadnim društvima) vizuelna umetnost najniže kotira, odnosno u činjenici da muzika spada u tzv. domene performanse koji iziskuju dugotrajan i naporan period vežbanja, što nije slučaj sa preostala dva domena (Winner 1996). Jedno novije istraživanje porodičnog 
konteksta dece darovite u oblastima muzike i vizuelnih umetnosti sugeriše da su roditelji muzički darovite dece znatno prijemčiviji za ograničavajuće vaspitne postupke usled naglašavanja važnosti "discipline", dok su se roditelji dece darovite za vizuelne umetnosti pokazali znatno otvorenijim i iskrenijim u komunikaciji sa decom (Freeman, 2000, prema: Pekić, 2010).

Osim porodice, značajan uticaj na ponašanje darovitih učenika - pa i na njihovo postignuće - svakako ima i vršnjačka grupa. Naime, mnoga istraživanja pokazala su da priklonjenost vršnjacima koji ostvaruju visok školski učinak deluje stimulativno na darovite učenike, i obratno. Primera radi, u istraživanju Rajsa i saradnika (Reis et al., 1995, prema: McCoach, 2002) ustanovljena je mogućnost poboljšanja učinka darovitih podbacivača nakon određenog perioda druženja sa učenicima koji ostvaruju visoko školsko postignuće. Sa druge strane, u istraživanjima uzroka podbacivanja darovitih učenika $66 \%$ proglašava negativan uticaj vršnjačke grupe jednom od glavnih prepreka aktuelizacije vlastitih potencijala (Clasen \& Clasen, 1995). Druga istraživanja, takođe, ukazuju na to da se "sila vršnjačke teže" nipošto ne sme potceniti: Bernt (Berndt, 1999, prema: Reis \& McCoach, 2000), na primer, nalazi da postignuće učenika teži da se približi postignuću njegovih drugova i da mu se ocene tokom godine smanjuju ukoliko su njegovi drugovi imali niže ocene u prvom polugodištu. Iako ovi nalazi ne impliciraju kauzalnost, budući da učenici često biraju za prijatelje osobe koje su im inače slične, oni podržavaju tezu da postoji značajna korelacija između postignuća učenika i postignuća njegove najbliže vršnjačke grupe (Berndt, 1999, prema: Reis \& McCoach, 2000).

Još upečatljivije podatke o prilagođavanju darovite dece akademskim normama grupe iznosi Grosova (Gross, 1998) na osnovu svoje studije ekstremno darovite dece: "Više od 70\% ispitnika koji su rano naučili da čitaju [...] radikalno je modifikovalo kvalitet svog čitanja ili sasvim prestalo da čita na času u roku od četiri nedelje od početka škole. Interesantno je da su kod kuće nastavili da čitaju jednako kvalitetno kao ranije. Promena u njihovom postignuću na času predstavljala je reakciju na jaku potrebu da se konformiraju ponašanju svojih vršnjaka" (Gross, 1998, prema: Altaras, 2006: 163).

Proučavanje sredinskih prilika koje potiču iz konteksta školske sredine ukazuje na to da pojedini načini organizacije nastavnog procesa nude osnovu za predviđanje postignuća darovitih učenika koji u njemu učestvuju. Pod organizacijom nastavnog procesa se, prevashodno, misli na realizaciju segmenata nastavnih aktivnosti u kojima do izražaja dolazi 
kompetitivnost učenika. Naime, s obzirom da je poznato da je sklonost ka takmičenju utoliko izraženija što su varijacije u sposobnostima učenika manje, kompetitivnost se može smatrati stalnim pratiocem aktivnosti darovitih učenika (Udvari \& Schneider, 2000). Imajući u vidu ranije pomenutu distinkciju između takmičenja sa sobom i takmičenja sa drugima, uspešnost darovitih učenika, barem izvesnim delom, može se objasniti nastavnom instrukcijom koja stavlja akcenat na unapređivanje kompetencije učenika u određenom domenu - umesto na demonstraciju vlastite superiornosti (Rimm, 1986, prema: Udvari \& Schneider, 2000). O boljem učinku ispitanika koji su određeni zadatak obavljali uz instrukciju da "daju sve od sebe", u odnosu na ispitanike kojima je prethodno najavljena ekspertska evaluacija krajnjeg ishoda zadate aktivnosti, svedoče mnoga savremena istraživanja (Collins \& Amabile, 1999).

Premda okruženje darovitih pojedinaca podrazumeva mogućnost naznačavanja njegovih različitih segmenata, doprinos ove grupe varijabli smatra se vrlo skromnim. U literaturi koja sistematizuje nalaze istraživanja ove problematike navode se barem dva moguća razloga ograničenog doprinosa sredinskih varijabli ostvarenju darovitosti - prvim razlogom se smatra način njihovog delovanja koji bi se pre mogao opisati terminima moderatorskog uticaja nego uticaja jasno izolovanih faktora, što za sobom povlači drugi razlog, sadržan u poteškoći jasnog operacionalizovanja ovakve vrste varijabli (Trost, 2000, prema: Štula, 2007).

\section{Zaključak}

Opšti nalaz svih pomenutih istraživanja može se izraziti sledećim rečima: sudbina izuzetnih potencijala umnogome zavisiodvanintelektualnih činilaca. Natprosečne sposobnosti su svakako važan elemenat darovitosti, jer omogućuju kvalitetnije bavljenje određenim aktivnostima, ali, same po sebi, one nisu dovoljne da bi se darovitost iskazala u izuzetnim postignućima. S druge strane, opstaje i uverenje da će "istinski" daroviti i vredni učenici biti uspešni u svim uslovima. Ovakvo stanovište donekle podržavaju rezultati jednog korijeg istraživanja kojim je utvrđeno da većina darovitih učenika, uprkos tome što obrazovni sistem opaža kao umnogome inkompatibilan sa sopstvenim (preferiranim) stilom učenja, ostvaruje visoko školsko postignuće; prema rečima istraživača, okruženje u kojem su ovi učenici funkcionisali nije se činilo toliko važnim koliko njihova lična volja da dosledno postižu dobar uspeh i ispunjavaju zadatke bez obzira 
na nivo izazova (Rayneri, Gerber \& Wiley, 2006). Iako ovakvi nalazi ne oslobađaju školu odgovornosti za ostvarenje darovitosti, oni podsećaju na to da se ova pojava može dovesti u vezu sa specifičnim svojstvima ličnosti osobe koja je aktuelizovala svoju darovitost. Pored "fluidne" potrebe za saznanjem (koja bi trebalo da je inherentna darovitosti), školska uspešnost zahteva, naime, i "kristalizovan" motiv postignuća i izgrađene veštine samoregulacije koje nisu svojstvene svim darovitim učenicima. Sve u svemu, pregled dosadašnjih istraživanja ukazuje na to da se iz domena personalnog kao ključni činioci ostvarenja darovitosti mogu izdvojiti: motivaciona svojstva, psihosocijalna prilagođenost, potreba za novim, drugačijim, izazovnim, visok stepen nezavisnosti, estetska osetljivost, izražena moralna osetljivost.

Premda osobe darovite u različitim domenima imaju mnoge zajedničke karakteristike, njihovi profili ličnosti pokazuju i određene specifičnosti, što upućuje na postojanje relacije između vrste domena i specifičnog kvaliteta darovitosti koja se u njemu manifestuje. Tako se uz umetničke vidove darovitosti, prevashodno, vezuju crte sa predznakom nekonvencionalnosti i nekonformizma, dok se akademska darovitost odlikuje sklonošću ka redu i organizovanosti. I uticaji sredine, u prvom redu porodice, pokazuju se specifičnim u zavisnosti od vrste domena manifestovanja darovitosti, te se muzička darovitost konzistentno povezuje sa naglašenom direktivnošću i restriktivnošću vaspitnog stila roditelja, zapaženi učinak u oblasti vizuelnih umetnosti sa popustljivim vaspitnim postupcima roditelja, dok su roditelji akademski darovite dece negde na prelazu između pomenutih vaspitnih stilova (Pekić, 2010). Sve ovo, naravno, ne znači nužno da domen oblikuje darovitu osobu i odnose u njenoj porodici. Važno je imati na umu da veza između svojstava ličnosti ili porodice darovitih osoba i domena u kojem se manifestuje darovitost može biti dvosmerna: kao što je moguće da se određeno ponašanje javlja kao odgovor na zahteve domena, tako je moguće i da darovita osoba, pored izuzetne sposobnosti, poseduje i druge dispozicije koje je usmeravaju ka određenom domenu, ili to čini porodica u skladu sa svojim prethodnim sklonostima (Altaras, 2006).

U svakom slučaju, nalazi o tome da darovitost podrazumeva različite konstelacije personalnih i sredinskih karakteristika u zavisnosti od vrste domena sa kojim individua ostvaruje interakciju, upućuju na zaključak da se fenomen darovitosti može precizno sagledati jedino ako se locira $u$ okvire pojedinačnih domena. Stoga se čini opravdanim zaključiti da osim 
multidimenzionalnosti, kao krucijalnog modernog obeležja konstrukta darovitosti, referentni okvir istraživanja ovog problema mora biti definisan i u terminima konkretnog domena manifestovanja izvrsnosti. Shvatanje Sternberga (Sternberg, 1990, prema: Heller \& Schofield, 2000: 123) koji ističe da "darovitost moramo razmatrati ne samo u terminima multiplih komponenti, nego i u terminima njenih različitih tipova" značajna je podrška navedenom stavu.

\section{EXTRA-INTELLECTUAL FACTORS FOR THE ACHIEVEMENT OF GIFTEDNESS}

\section{SUMMARY}

Abstract: Starting from the contemporary conceptions of giftedness, which emphasize the importance of personal and environmental characteristics for updating the high abilities, the authors of the paper provide an overview of the research dealing with the influence of personality traits and environment circumstances to the achievement of giftedness by using the method of theoretical analysis. There has been made an attempt to complement the knowledge on extraintellectual sphere of the gifted, hoping to get a more comprehensive picture of factors for the achievement of the gifted than the one that is currently available. The overall findings of all the aforementioned researches are contained in the statement that a destiny of the exceptional potentials largely depends on the extraintellectual factors. Above-average skills are certainly an important element of giftedness, since they allow better performing of certain activities. However, by themselves they are not enough to convey the giftedness in exceptional achievements.

Although persons gifted in different domains have many common characteristics, their personality profiles, and environmental opportunities show certain specificities, what leads to the conclusion that the phenomenon of giftedness can be accurately viewed only if it is located in the framework of individual domains. Therefore, the authors conclude that in addition to the multi-dimensionality, as the crucial modern characteristic of the construct of giftedness, the reference framework of the research of this problem must be defined in terms of the specific domain of manifesting excellence.

Key words: giftedness, giftedness achievement personality traits, environmental opportunities. 


\section{Literatura}

Altaras, A. (2006). Darovitost i podbacivanje. Pančevo: Mali Nemo. Ames, C. (1992). Classroom goals, structures and student motivation. Journal of Educational Psychology, Vol. 84, No. 3, 261-271.

Ayduk, O. \& Mischel, W. (2002). When smart people behave stupidly: Reconciling inconsistencies in social-emotional intelligence. In R. J. Sternberg (Ed.), Why smart people can be so stupid (pp. 86-105). New Haven: Yale University Press.

Baker, J. A., Bridger, R. \& Evans, K. (1998). Models of underachievement among gifted preadolescents: The role of personal, family, and school factors. Gifted Child Quarterly, Vol. 42, No. 1, 5-15.

Baum, S. M., Renzulli, J. S. \& Hébert, T. P. (1995). Reversing underachievement: Creative productivity as a systematic intervention. Gifted Child Quarterly, Vol. 39, No. 4, 224-235.

Chamorro-Premuzic, T. \& Furnham A. (2003). Personality traits and academic examination performance, European Journal of Psychology, Vol. 17, No. 3, 237-250.

Clasen, D. R., \& Clasen, R. E. (1995). Underachievement of highly able students and the peer society. Gifted and Talented International, Vol. 10, No. 2, 67-75.

Collins, M. A. \& Amabile, T. M. (1999). Motivation and creativity. In R. J. Sternberg (Ed.). Handbook of creativity (pp. 297-313). Cambridge: Cambridge University Press.

Díaz,E.(1998). Perceived factorsinfluencing theacademicunderachievement of talented students of Puerto Rican descent. Gifted Child Quarterly, Vol. 42, No. 2, 105-122.

Edmunds, A. L. \& Edmunds, G. A. (2005). Sensitivity: A double-edged sword for the pre-adolescent and adolescent gifted child. Roeper Review, Vol. 27, No. 2, 69-84.

Feist, G. J. (1999). Personality in scientific and artistic creativity. In R. J. Sternberg (Ed.). Handbook of creativity (pp. 273-296). Cambridge: Cambridge University Press.

Feldhusen, J. F. \& Jarwan, F. A. (2000). Identification of gifted and talented youth for educational programs. In K. A. Heller, F. J. Mönks, R. J . Sternberg \& R. Subotnik (Eds.), International handbook of giftedness and talent (pp. 271-282). Oxford: Elsevier science.

Franken, R. E., \& Brown, D. J. (1995). Why do people like competition? The motivation for winning, putting forth effort, improving one's performance, performing well, being instrumental, and expressing 
forceful/aggressive behavior. Personality and Individual Differences, Vol. 19, No. 2, 175-184.

Ford, D. Y. (1993). An investigation on the paradox of underachievement among gifted Black students. Roeper Review, Vol. 16, No. 2, 78-84.

Freeman, J. (2000). Families: the essential context for gifts and talents. In K. A. Heller, F. J. Mönks, R. J. Sternberg \& R. Subotnik (Eds.), International handbook of giftedness and talent (pp. 573-587). Oxford: Elsevier science.

Gagné, F. (2005). From gifts to talents: The DMGT as a developmental model. In R. J. Sternberg \& J. E. Davidson (Eds.), Conceptions of giftedness (pp. 98-120). New York: Cambridge University Press.

Gross, M. U. M. (1998). The „me“ behind the mask: Intellectually gifted students and the search for identity. Roeper Review, Vol. 20, No. 3, $167-174$.

Heller, K. A., Schofield, N. J. (2000). International trends and topics of research on giftedness and talent. In K. A. Heller, F. J. Mönks, R. J . Sternberg, R. Subotnik (Eds.), International handbook of giftedness and talent (123-137). Oxford: Elsevier science.

Heller, K. A., Perleth, C. \& Lim, K. (2005). The munich model of giftedness designed to identify and promote gifted students. In R. J. Sternberg \& J. E. Davidson (Eds.), Conceptions of giftedness (pp. 147-170). New York: Cambridge University Press.

Laidra, K., Pullmann, H. \& Allik J. R. (2007). Personality and intelligenceas predictors of academic achievement: a cross-sectional study from elementary to secondary school. Personality and Individual Differences, Vol. 42, No. 3, 441-451.

Lovecky, D. V. (1992). Exploring social and emotional aspects of giftedness in children. Roeper Review, Vol. 15, No. 1, 18-25.

Lovecky, D. V. (1997). Identity development in gifted children: Moral sensitivity. Roeper Review, Vol. 20, No. 2, 90-94.

Maddux, C. D., Scheiber, L. M. \& Bass, J. E. (1982). Self-concept and social distance in gifted children. Gifted Child Quarterly, Vol. 26, No. 2, 77-81.

Martin, J., Montgomery, R. \& Saphian, D. (2006). Personality, achievement test scores and high school percentiles as predictors of academic performance across four years of coursework. Journal of Research in Personality, Vol. 40, No. 4, 424-431.

McCoach, D. B. (2002). A validation study of the school attitude assessment survey. Measurement and evaluation in counseling and development, Vol. 35, No. 2, 66-99. 
Morelock, M. J. (1997). In response to Gagné's critique. Roeper Review, Vol. 20, No. 2, 85-87.

Naderi, H., Abdullah, R., Aizan, H.T., Sharir, J., \& Kumar, V. (2010). Relationship between creativity and academic achievement: A study of gender differences. Journal of American Science, Vol. 6, No. 1, $181-190$.

O’Connor, M. C. \& Paunonen S. V. (2007). Big Five personality predictors of post-secondary academic performance. Personality and Individual Differences, Vol. 43, No. 2, 971-990.

Olenchak, F. R. (1999). Affective development of gifted students with nontraditional talents. Roeper Review, Vol. 21, No. 4, 293-297.

Palaniappan, A. K. (2005). Creativity and academic achievement: A Malaysian perspective. Shah Alam: Karis Publications.

Parker, W. D. \& Adkins, K. K. (1995). Perfectionism and the gifted. Roeper Review, Vol. 17, No. 3, 173-176.

Pekić, J. (2010). Uloga domena u nastanku specifičnog kvaliteta darovitosti. Godišnjak Filozofskog fakulteta u Novom Sadu, God. 35, Br. 1, 193205.

Peters, W. A. M., Grager-Loidl, H. \& Supplee, P. (2000). Underachievement in gifted children and adolescents: Theory and practice. In K. A. Heller et al. (Eds.), International andbook of Giftedness and Talent (pp. 609-620). Oxford: Elsevier.

Peterson, J. S. (2001). Gifted and at-risk: Four longitudinal case studies of posthigh-school development. Roeper Review, Vol. 24, No. 1, 31-39.

Poropat, A. E. (2009). A meta-analysis of the five-factor model of personality and academic performance. Psychological Bulletin, Vol. 135, No. 2, 322-338.

Poropat, A. E. (2011). The Eysenckian personality factors and their correlations with academic performance. British Journal of Educational Psychology, Vol. 81, No. 1, 41-58.

Rayneri, L. J., Gerber, B. L. \& Wiley, L. P. (2006). The relationship between classroom environment and the learning style preferences of gifted middle school students and the impact on levels of performance. Gifted Child Quarterly, Vol. 50, No. 2, 104-118.

Reis, S. M. \& McCoach, D. B. (2000). The underachievement of gifted students: What do we know and where do we go? Gifted Child Quarterly, Vol. 44, No. 3, 152-170.

Renzulli, J. S. \& Park, S. (2000). Gifted dropouts: The who and the why. Gifted Child Quarterly, Vol. 44, No. 4, 261-271.

Sak, U. (2004). A synthesis of research on psychological types of gifted 
adolescents. Journal of Secondary Gifted Education, Vol. 15, No. 2, 70-92.

Siegle, D. \& Schuler, P. A. (2000). Perfectionism differences in gifted middle school students. Roeper Review, Vol, 23, No. 1, 39-44.

Silverman, L. K. (1994). The moral sensitivity of gifted children and the evolution of society. Roeper Review, Vol. 17, No. 2, 110-116.

Silverman, L. K. (1998). Through the lens of giftedness. Roeper Review, Vol. 20, No. 3, 204-210.

Štula, J. (2007). Osobine ličnosti kao činioci uspešnosti učenika srednjih škola za darovite. Neobjavljen magistarski rad, Beograd: Filozofski fakultet.

Tan-Willman, C. \& Gutteridge, D. (1981). Creative thinking and moral reasoning in academically gifted secondary school students. Gifted Child Quarterly, Vol. 25, No. 4, 149-153.

Tolan, S. S. (1998). The Lemming Condition: Moral asynchrony and the isolated self. Roeper Review, Vol. 20, No. 3, 211-214.

Torrance, E. P. (2004). The role of creativity in identification of the gifted and talented. In D. J. Treffinger (Ed.), Creativity and giftedness (pp. 79-87). Thousand Oaks: Corwin Press.

Trost, G. (2000). Prediction of exellence in school, higher education and work. In K. Heller, F. Mönks, R. Sternberg \& R. Subotnik (Eds.), Giftedness and talent, (pp. 317-327). Oxford: Elsevier science.

Udvari, S. J. \& Schneider, B. H. (2000). Competition and the adjustment of gifted children: a matter of motivation. Roeper Review, Vol. 22, No. 4, 212-227.

Uguroglu, M. E. \& Walberg, H. J. (1979). Moivation and achievement: a quantitative synthesis. American Educational Research Journal, Vol. 16, No. 4, 375-389.

Winner, E. (1996). Gifted children: Myths and realities. New York: Basic Books.

Zuo, L. \& Cramond, B. (2001). An examination of Terman's gifted children from the theory of identity. Gifted Child Quarterly, Vol. 45, No. 4, 251-259. 